\title{
Success Cases of Rice Farmers under RKVY Scheme at DAATTC, Ranga Reddy District India
}

\author{
N. Praveen ${ }^{1 *}$, P. Ammaji ${ }^{2}$, C.H. Chiranjeevi ${ }^{3}$ and J.S. Sudharani ${ }^{2}$ \\ ${ }^{1}$ (Agril. Extension) \& Coordinator, ${ }^{2}$ Crop Production, and ${ }^{3}$ Plant Protection \\ District Agricultural Advisory and Transfer of Technology Centre, PJTSAU Telangana, India \\ *Corresponding author
}

\begin{abstract}
Keywords
Rice farmers,

RKVY scheme,

Biointensive pest

management

Article Info

Accepted:

18 October 2018

Available Online:

10 November 2018 Rs 4,09090/- was allocated to DAATTC, Ranga Reddy PJTSAU during 2012-2014 for organizing onfarm testing, Farmers training programmes and exposure visits. Farmers of Ranga Reddy District cultivate rice in a larger area as major food crop. To enhance the yields by adopting five improved technologies. i.e. Direct sowing with 8 row drum seeder resulted on $9.5 \%$ increased yields $6451 \mathrm{~kg} / \mathrm{ha}$ are normal sowing $5890 \mathrm{~kg} / \mathrm{ha}$. JGL 1118 variety has recorded $6698 \mathrm{~kg} / \mathrm{ha}$ of yield when compared to $6147 \mathrm{~kg} / \mathrm{ha}$ when normally sown. Line planting of Rice seedlings, given an average yield of $6343 \mathrm{~kg} / \mathrm{ha}$ as against normal planting $(5416 \mathrm{~kg} / \mathrm{ha})$.The intervention gave $14.6 \%$ increase in yield when compared to normal planting.(SRI) System of Rice Intensification, SRI cultivation recorded an average yield of $6266 \mathrm{~kg} / \mathrm{ha}$ where has normal planting has recorded 5226 $\mathrm{kg} / \mathrm{ha}$. Biointensive pest management, BIPM has also recorded $2351 \mathrm{~kg}$ per acre against $1944 \mathrm{~kg} /$ arced in farmers practice, showing that the BIPM will be useful to the farmers in reducing pest incidence and getting higher yields in Rice. Use of Liquid biofertilizers, resulted effective tillers per hill (33.4/hill), more percent of filled grain per panicle (86\%) and more yield $2480 \mathrm{~kg} / \mathrm{ac}$ with $1.55 \mathrm{CB}$ ratio.
\end{abstract}

A B S T R A C T

Rashtriya Krishi Vikas Yojana is a State Plan Scheme of Additional Central Assistance launched in August 2007 as a part of the 11th Five Year Plan by the Government of India under National Development Council, to achieve 4\% annual growth in agriculture through development of Agriculture and its allied sectors. A fund of

\section{Introduction}

Rashtriya Krishi Vikas Yojana is a State Plan Scheme of Additional Central Assistance launched in August 2007 as a part of the 11th Five Year Plan by the Government of India under National Development Council, to achieve $4 \%$ annual growth in agriculture through development of Agriculture and its allied sectors. A fund of Rs 4,09090/- was allocated to DAATTC, Ranga Reddy PJTSAU during 2012-2014 for organizing onfarm testing, Farmers training programmes and exposure visits. As farmers of Ranga Reddy District cultivate rice in a larger area as major food crop. To enhance the yields by adopting five improved technologies. i.e. Direct sowing with 8 row drum seeder, Line planting of Rice seedlings, (SRI) System of Rice Intensification, Biointensive pest management and Liquid biofertilizers. as on farm testing were grounded in the district i.e. were 
grounded in 25 beneficiaries of 11 mandals at Ranga Reddy District.

The impact of few success cases under RKVY scheme is presented below

\section{Direct sowing with 8 row drum seeder}

In Ranga Reddy district labour availability during transplanting season is a major constraint. Not only for transplanting the other operations like weeding, harvesting etc also require more labours. In order to overcome the major limiting factor of labour in Paddy cultivation, the drum seeder sowing was introduced to Ranga Reddy district farmers by DAATTC, Gudimalkapur under RKVY programme (Table 1).

"8" row drum seeder was used for sowing of two Paddy varieties JGL -17004 and JGL1118 in 8 locations. For sowing with 8 row drum seeder, the seed was pre soaked for 24 hours followed by incubation for 12 hours to just germinate the seed. The seed drum of the drum seeder will be filled up to $3 / 4$ th capacity and the drum seeder is dragged on uniformly leveled per watered field for the management of weeds, pre and post emergence weedicides were recommended. Pre emergence weedicides like Oxadiarzyl was applied to control the weeds. But phytotoxic symptoms were noticed when field was not properly tilled.

Due to severe cold and low temperatures, germination was delayed by 7-10 days resulting in early emergence of weed. In the management of these weeds post emergence weedicides like Nominee gold @ 80-100gr/Ac was recommended.

Sowing with "8" row drum seeder resulted on $9.5 \%$ increased yields $6451 \mathrm{~kg} / \mathrm{ha}$ are normal sowing5890 kg/ha. JGL -1118 variety has recorded $6698 \mathrm{~kg} / \mathrm{ha}$ of yield when compared to $6147 \mathrm{~kg} / \mathrm{ha}$ when normally sown. The varieties recorded 22 average tillers/hill with 265 grains /panicle. JGL 17004 variety has recorded an average yield of $6204 \mathrm{~kg} / \mathrm{ha}$ when sown with 8 row drum seeder and $5686 \mathrm{~kg} / \mathrm{ha}$ with normal sowing. This variety has recorded 18 tillers/hill and 275 grains/panicle (Table 2).

\section{Advantages}

Crop comes to harvest 7-10 days when compared to transplanted rice.

Sowing of labours and reduction in cost of cultivation on nursery management is skipped. Labour cost is further reduced with the usage of pre and post emergence weedicides.

Average yields (kg/ha) also increased by $9.5 \%$

\section{Disadvantages}

Severe cold and low temperature conditions may enhance the time for germination.

If rains occur within 12 hours after sowing, the seed gets disturbed.

Farmers are facing marketing problem as the millers are objecting that the grains are breaking during milling.

\section{Line planting of rice seedlings}

Evaluation of line planting was done in four locations in Doma mandal and village of Ranga Reddy district with variety JGL 1118 during 2012-13 Rabi season.15-20 deep old Paddy seedlings were transplanted with a spacing of $20 \mathrm{~cm}$ between the line.1-2 seedlings were planted per hill. In this method also Cono weeder was used on one side to reduce for weeds. Recommended N, P, K fertilizers were applied as per university recommendations. Line planting intervention has given an average yield of $6343 \mathrm{~kg} / \mathrm{ha}$ as against normal planting (5416 kg/ha).The intervention gave $14.6 \%$ increase in yield when compared to normal planting (Table 3 ). 


\section{System of Rice Intensification (SRI)}

Evaluating of SRI method of Paddy cultivation with 15-17 days old seedling instead of 8-10 days old seedling was done in 4 locations of Doma and Parigi mandals. MTU 1010 variety was used as test variety which is of 120 days duration (Table 5).

Trans planting was done with 15-17 days old seedlings, at a spacing of $20 \mathrm{~cm}$ and $1-2$ seedlings per hill. Cono weeder was used to suppress the weeds for 3-4 times. Recommended N,P,K was applied as per university recommendations.

The variety MTU 1010 gave 6.5\% more yield with SRI transplanting when compared to normal planting. SRI cultivation recorded an average yield of $6266 \mathrm{~kg} / \mathrm{ha}$ where has normal planting has recorded $5226 \mathrm{~kg} / \mathrm{ha}$. SRI transplanted Paddy came to harvest 7-10 days early than normal planted Paddy.

\section{Advantages}

Crop came to harvest 5-7 days early than normal planting.

Less seed rate $(2-3 \mathrm{~kg} / \mathrm{ac})$ when compared to normal planting.

Management of weed is easy as cono weeder is used in SRI transplanting.

Gave more yield than normal planting.

SRI cultivation is being adopted by number of farmers in Ranga Reddy district in Doma mandal.

\section{Disadvantages}

Labour cost is more.

Availability of labours for line planting is the major constraint.

Table.1 Details of 8 row drum seeder in rice

\begin{tabular}{|c|c|c|c|c|c|c|c|c|}
\hline \multirow{2}{*}{$\begin{array}{l}\text { S. } \\
\text { No }\end{array}$} & \multirow{2}{*}{$\begin{array}{l}\text { Name of the } \\
\text { farmer }\end{array}$} & \multirow{2}{*}{$\begin{array}{l}\text { Village and } \\
\text { address }\end{array}$} & \multirow[t]{2}{*}{ Variety } & \multirow[t]{2}{*}{ Duration } & \multirow{2}{*}{$\begin{array}{l}\text { Date of } \\
\text { sowing }\end{array}$} & \multirow{2}{*}{$\begin{array}{l}\text { Date of } \\
\text { Harvesting }\end{array}$} & \multicolumn{2}{|c|}{ Yield, kg/ha } \\
\hline & & & & & & & Demo & Control \\
\hline 1 & V. Ramesh & Doma $(\mathrm{m} \& \mathrm{~V})$ & JGL-1118 & 100 & $17-1-13$ & $7-5-13$ & 6180 & 5846 \\
\hline 2 & $\begin{array}{l}\text { M.Ramchandr } \\
\text { a Reddy }\end{array}$ & Doma $(m \& V)$ & JGL-1118 & 100 & $7-1-13$ & $17-4-13$ & 7050 & 6428 \\
\hline 3 & $\begin{array}{l}\text { M.Chandra } \\
\text { Reddy }\end{array}$ & Doma $(\mathrm{m} \& \mathrm{~V})$ & JGL-1118 & 120 & $5-1-13$ & $27-4-13$ & 6775 & 5887 \\
\hline 4 & $\begin{array}{l}\text { M.Krishna } \\
\text { Reddy }\end{array}$ & $\begin{array}{l}\text { Parepally(v) } \\
\text { Doma (m) }\end{array}$ & JGL-1118 & 120 & $17-1-13$ & $6-5-13$ & 6548 & 6120 \\
\hline \multirow[t]{2}{*}{5} & $\begin{array}{l}\text { Nageshwara } \\
\text { Rao }\end{array}$ & $\begin{array}{l}\text { Haridaspally, } \\
\text { Keesara (m) }\end{array}$ & JGL-1118 & 120 & $18-1-13$ & $7-5-13$ & 6940 & 6454 \\
\hline & & \multicolumn{5}{|c|}{ Total average } & 6698 & 6147 \\
\hline 6 & Md.Kursheed & $\begin{array}{l}\text { Haridaspally, } \\
\text { Keesara (m) }\end{array}$ & JGL-17004 & 120 & $17-1-13$ & $10-5-13$ & 6140 & 5570 \\
\hline 7 & R.Satti Reddy & $\begin{array}{l}\text { Cheryal, } \\
\text { Keesara (m) }\end{array}$ & JGL-17004 & 120 & $5-1-13$ & $28-5-13$ & 6387 & 5645 \\
\hline \multirow[t]{2}{*}{8} & G.Vijay Rao & Doma $(m \& V)$ & JGL-17004 & 100 & $20-1-13$ & $3-5-13$ & 6085 & 5686 \\
\hline & & & \multicolumn{4}{|c|}{ Total average } & 6204 & 5633 \\
\hline
\end{tabular}


Table.2 Growth and yield attributes of JGL-1118 and JGL-17004

\begin{tabular}{|c|c|c|}
\hline & JGL-1118 & JGL-17004 \\
\hline Tillers / hill & 22 & 18 \\
\hline Plant height $(\mathbf{c m})$ & 93 & 95 \\
\hline Panicle length $(\mathbf{c m})$ & 24 & 23 \\
\hline Grains/panicle & 265 & 275 \\
\hline
\end{tabular}

Table.3 Details of line planting of rice seedlings

\begin{tabular}{|c|c|c|c|c|c|c|c|c|}
\hline \multirow{2}{*}{$\begin{array}{l}\text { S. } \\
\text { No }\end{array}$} & \multirow{2}{*}{$\begin{array}{l}\text { Name of the } \\
\text { farmer }\end{array}$} & \multirow{2}{*}{$\begin{array}{l}\text { Village and } \\
\text { address }\end{array}$} & \multirow[t]{2}{*}{ Variety } & \multirow[t]{2}{*}{ Duratio } & \multirow{2}{*}{$\begin{array}{l}\text { Date of } \\
\text { sowing }\end{array}$} & \multirow{2}{*}{$\begin{array}{c}\text { Date of } \\
\text { Harvesting }\end{array}$} & \multicolumn{2}{|c|}{ Yield, kg/ha } \\
\hline & & & & & & & Demo & Control \\
\hline 1 & S.Sanjeev & $\begin{array}{l}\text { Parepally(v) } \\
\text { Doma (m) }\end{array}$ & JGL-1118 & 120 & $14-1-13$ & $5-5-13$ & 6015 & 5435 \\
\hline 2 & K Rami Reddy & Doma $(\mathrm{m} \& \mathrm{~V})$ & JGL-1118 & 120 & $15-1-13$ & $7-5-13$ & 6425 & 5185 \\
\hline 3 & K. Krishna Reddy & Doma $(\mathrm{m} \& \mathrm{~V})$ & JGL-1118 & 120 & $15-1-13$ & $8-5-13$ & 6656 & 5285 \\
\hline 4 & K. Dasthaiah & Doma $(\mathrm{m} \& \mathrm{~V})$ & JGL-1118 & 100 & $15-1-13$ & $10-5-13$ & 6275 & 5760 \\
\hline & Avg & & & & & & 6342.75 & 5416.25 \\
\hline
\end{tabular}

Table.4 Details of bio intensive pest management

\begin{tabular}{|c|c|c|c|c|c|c|c|}
\hline \multirow[t]{2}{*}{ S.No } & \multirow[t]{2}{*}{$\begin{array}{l}\text { Name of } \\
\text { Location/ } \\
\text { Farmer }\end{array}$} & \multicolumn{2}{|c|}{$\begin{array}{c}\text { White ears } \\
\text { (from } 20 \text { randomly } \\
\text { selected plants) }\end{array}$} & \multicolumn{2}{|c|}{ Yield/acre } & \multicolumn{2}{|c|}{ CB Ratio } \\
\hline & & BIPM & FP & BIPM & FP & BIPM & FP \\
\hline 1 & $\begin{array}{l}\text { G. Narayana Rao } \\
\text { Gaddipalli (v)Darur(m) }\end{array}$ & 2 & 5 & 6144 & 4440 & 2.05 & 1.27 \\
\hline 2 & $\begin{array}{l}\text { B. Ramulu Gaddipally } \\
\text { (v)Darur (m) }\end{array}$ & 2 & 4 & 5328 & 4236 & 1.78 & 1.21 \\
\hline 3 & $\begin{array}{l}\text { C.Yadaiah Gaddipally(v) } \\
\text { Darur(m) }\end{array}$ & 1 & 6 & 5628 & 4884 & 1.88 & 1.40 \\
\hline 4 & $\begin{array}{l}\text { K.Rajender Gollapally(v) } \\
\text { Darur(m) }\end{array}$ & 3 & 7 & 5268 & 4668 & 1.76 & 1.33 \\
\hline 5 & $\begin{array}{l}\text { K.Bakka Reddy } \\
\text { Gaddipally(v) } \\
\text { Darur }(\mathrm{m})\end{array}$ & 2 & 5 & 5844 & 5100 & 1.95 & 1.46 \\
\hline \multicolumn{2}{|c|}{ Average } & 10 & 27 & 5642.4 & 4665.6 & 1.88 & 0.67 \\
\hline
\end{tabular}


Table.5 Details of system of rice intensification

\begin{tabular}{|c|c|c|c|c|c|c|c|c|}
\hline $\begin{array}{c}\text { S. } \\
\text { No }\end{array}$ & $\begin{array}{c}\text { Name of the } \\
\text { farmer }\end{array}$ & Village and address & Variety & Duration & \multicolumn{2}{|c|}{$\begin{array}{c}\text { Date of } \\
\text { sowing }\end{array}$} & $\begin{array}{c}\text { Date of } \\
\text { Harvesting }\end{array}$ & \multicolumn{2}{|c|}{ Yiemo } & Dem/ha \\
\hline $\mathbf{1}$ & $\begin{array}{c}\text { Satyanarayan } \\
\text { reddy }\end{array}$ & Doma (m \& V) & MTU-1010 & 100 & $16-1-13$ & $30-4-13$ & 6145 & 5685 \\
\hline $\mathbf{2}$ & Prabhulingam & Parepally(v) Doma (m) & MTU-1010 & 100 & $17-1-13$ & $30-4-13$ & 6585 & 5945 \\
\hline $\mathbf{3}$ & S.Sanjeev & Parepally(v) Doma (m) & MTU-1010 & 120 & $14-1-13$ & $6-5-13$ & 5875 & 5265 \\
\hline $\mathbf{4}$ & C.Yadaiah & Gaddipally(v)Darur(m) & MTU-1010 & 120 & $15-1-13$ & $7-5-13$ & 6461 & 5210 \\
\hline & Avg & & & & & 6266.5 & 5526.25 \\
\hline
\end{tabular}

Table.6 Details of liquid biofertilizers

\begin{tabular}{|l|l|l|l|l|l|}
\hline Treatments & $\begin{array}{l}\text { No. } \\
\text { tillers } \\
\text { per hill }\end{array}$ & $\begin{array}{l}\text { No. of } \\
\text { effective } \\
\text { tillers per } \\
\text { hill }\end{array}$ & $\begin{array}{l}\text { Percentage of } \\
\text { filled grains per } \\
\text { panicle }\end{array}$ & $\begin{array}{l}\text { Grain Yield } \\
\text { per }\end{array}$ & $\begin{array}{l}\text { Cost } \\
\text { Benefit } \\
\text { ratio }\end{array}$ \\
\hline Farmer's Practice & 28 & 23 & 86 & 5040 & $1: 1.21$ \\
\hline Liquid Bio-fertilizers with 75\% RDF & 45 & 38 & 85 & 6360 & $1: 1.62$ \\
\hline $\mathbf{1 0 0 \% ~ R D F ~}$ & 37 & 32 & 75 & 5616 & $1: 1.30$ \\
\hline Avg & 36.6 & 31 & 87 & 5672 & $1: 1.37$ \\
\hline
\end{tabular}

*RDF: Recommended dose of fertilizer

\section{Biointensive pest management}

The trial on Bio intensive pest management along with farmers practice was conducted in ' 5 ' location in Dharur Mandal. In bio intensive pest management the components like Tirchocards, Pheromone traps were used where as in farmers practice no components were added (Table 4).

Regarding the pest incidence, low incidence of stem borer (dead hearts), leaf folder, Rice skipper, caseworm and hairy caterpillar were noticed during the crop growth period. No sucking pests were observed. Very low infestations of white ears were noticed at the time of harvest. An average of 0.5 white ears/will were recorded in BIPM where as 1.35 white ears/hill were recorded in farmers practice. BIPM has also recorded $2351 \mathrm{~kg}$ per acre against $1944 \mathrm{~kg} /$ arced in farmers practice, showing that the BIPM will be useful to the farmers in reducing pest incidence and getting higher yields in Rice.

\section{Liquid biofertilizers}

The trial was conducted in 5 locations in villages of Ranga Reddy, Ibrahimpatnam and Doma mandals out of three treatments evaluated, application of liquid bio fertilizer along with $75 \%$ of RDF gave more number of tillers/hill (39.6/hill) more number of effective tillers per hill (33.4/hill), more percent of filled grain per panicle $(86 \%)$ and more yield $2480 \mathrm{~kg} / \mathrm{ac}$ with $1.55 \mathrm{CB}$ ratio. The treatment with $100 \%$ RDF has reduced a $\mathrm{CB}$ ratio of 1.30 and farmers practices has given 1.21 $\mathrm{CB}$ ratio (Table 6).

The activities taken up and implemented used under RKVY scheme helped the farming 
community in many folds. The success stories documented on the impact of Direct sowing with 8 row drum seeder, Line planting of Rice seedlings, (SRI) System of Rice Intensification, Biointensive pest management and Liquid biofertilizers. As on farm testing were grounded in the district i.e. were grounded in 25 beneficiaries of 11 mandals at RangaReddy District. Motivated the other farmers to adopt the same.

\section{References}

Rashtriya Krishi Vikas Yojana 2014: Operational guidelines for XII five year plan Department of Agriculture and Cooperation, Ministry of Agriculture, Government of India.

Annual progress reports DAATTC, Ranga Reddy PJTSAU during 2013-2014, 2014-2015 and 2015-2016.

\section{How to cite this article:}

Praveen, N., P. Ammaji, C.H. Chiranjeevi and Sudharani, J.S. 2018. Success Cases of Rice Farmers under RKVY Scheme at DAATTC, Ranga Reddy District, India. Int.J.Curr.Microbiol.App.Sci. 7(11): 2455-2460. doi: https://doi.org/10.20546/ijcmas.2018.711.280 